\title{
Exploring the e-teaching and learning experiences of lecturers amidst COVID-19 at one of the University of Namibia satellite campuses
}

\author{
Anna Niitembu Hako \\ University of Namibia \\ Elina Ileimo Tobias \\ University of Namibia \\ Kleopas Erastus \\ University of Namibia \\ Doi:10.19044/ejes.v8no4a92 \\ URL:http://dx.doi.org/10.19044/ejes.v8no4a92 \\ Submitted: 11 August 2021 \\ Accepted: 16 December 2021 \\ Published: 31 December 2021 \\ Copyright 2021 Author(s) \\ Under Creative Commons BY-NC-ND \\ 4.0 OPEN ACCES
}

\section{ABSTRACT}

The study explored the e-teaching and learning experiences of lecturers amidst the COVID-19 pandemic at one of the University of Namibia satellite campuses. The study sample was 76 selected using the purposive sampling method from the population of 98 . The study used a convergent parallel research design within a mixed methods research approach. A survey questionnaire and telephone interview were used to collect data. Data collected from open-ended questions and telephone interviews were analysed and categorised into themes while quantitative data were tabulated and analysed mainly by descriptive statistics with the use of Microsoft Excel. The study revealed that participants found using Moodle and other e-learning tools efficient as they save time and reduce the chances of spreading the virus since no gatherings were required. The study further revealed that participants had an opportunity to learn new skills despite not having prior experience in online teaching and learning as well as online course design. However, regular power outages and server incapacity to accommodate multiple devices caused many lecturers and students to miss virtual lessons. The study provided crucial information on the progress of lecturers and students' within the e-teaching and learning mode framework and recommended the campus server upgrading and the formal training of both lecturers and students on online teaching and learning tools to optimise learning. 
Keywords: Online teaching, Learning tools, Virtual classes, Coronavirus, amidst, e-teaching,

\section{Introduction and Background of the Study}

The spread of the coronavirus disease (COVID-19) across the globe has locked the earth. A third of the world is under lockdown measures (Wango, 2020). In an attempt to contain the virus, the Namibian president declared COVID-19 a national pandemic and called for a state of emergency with effect from the $16^{\text {th }}$ of March 2020 to the 17 th of September 2020. This call led to the suspension of all public gatherings in the country, including schools and church services, institutions of higher learning and non-essential business activities, restricting public gatherings to a maximum of 10 people at one point. In addition to that, the president also called for the complete lockdown of the Khomas and Erongo regions in an attempt to curb the virus, but this was later extended to all 14 regions. Thus far, over 157 countries have imposed full or partial lockdowns as the number of people dying and testing positive keeps rising (Ndala, 2020). As of 11 August 2021, Namibia has 121603 confirmed coronavirus cases, 104858 recoveries and 3226 deaths; however, the number of cases increases daily (MoHSS, 2020).

Even though institutions of higher learning adhered to the call of social distancing and suspending large gatherings, the service delivery of the University of Namibia (UNAM) was not halted. It was still expected from the lecturers to prepare and present lessons and give assessment activities to students using online platforms. For instance, lecturers had to record audios/videos and prepare notes and upload them on various modes of elearning such as Moodle, Panopto and Google drive. Some have even used WhatsApp due to a lack of knowledge and skills on how to use Moodle as the preferred online university platform.

With the current advances in Information and Communication Technologies (ICTs) by way of improved computer power, faster data transfer rates, coupled with the fact that the effective integration of these technologies into educational curricula has been demonstrated to have positive effects on student learning (Harvey, 2003; Kiluk, 1994; Salpeter, 1998, as cited in Asunka, 2008), technology-enabled instruction, especially online teaching and learning, have emerged as the most feasible and economically sound means of expanding access to quality higher education. Online teaching and learning are thus being rapidly adopted by educational institutions worldwide as alternative or complementary modes of education delivery, and indeed have been indicated as the next democratizing force in education, particularly in higher education.

UNAM supports the international use of Technology-enhanced learning to increase equity, enhance efficiency and improve the quality of teaching and learning. To develop as a leading national institution in learning, 
teaching and research, and to cultivate standards of excellence in all functions prescribed by the University of Namibia Act No. 18 of 1992, the University will take full advantage of opportunities provided by ICTs to provide instructors and students with a technology-rich physical and online learning environment that is designed to appreciate diverse teaching and learning style preferences and accommodate the diversity of its users. This initiative provides the basis to harmonize Technology-enhanced Learning implementation across the University and to also guide staff in the process of planning, design, development and delivery of Technology-enhanced modules and module units (e-Learning policy, 2018). However, the move towards eLearning as a primary mode of learning did not come without challenges, both for lecturers and students. The results of this study may contribute to the growing body of knowledge on higher education and be useful to lecturers, higher institutions management, policy and professional programmes developers in the university. Therefore, the purpose of the study is to find out the teaching and learning experiences of lecturers with Moodle and other online teaching and learning platforms in semester 1 of 2020 during the state of emergency. Further, the researchers would like to uncover the good practices that lecturers use during the state of emergency specifically in semester 1 of 2020 that can be helpful to other lecturers when sharing knowledge and skills of online teaching.

\section{Statement of the problem}

UNAM had implemented Moodle and other online teaching and learning platforms for a few of its modules such as Contemporary Social Issues; English Communication and Study Skills. since 2018. The introduction of the blended teaching and learning mode was accompanied by several training workshops, but these were not compulsory. Although the idea was to gradually introduce the blended mode of teaching and learning for all the university modules, nobody anticipates that there would be a global pandemic that would prompt a rapid shift in 2020. Due to the outbreak of COVID-19, UNAM deployed e-learning on a full scale and it was expected that all lecturers comply with the new ways of instruction and assessment. Ideally, the introduction of changes and innovations should be gradual, well prepared and well-integrated with the rest of the courses to allow lecturers and students to make effective use of the new technologies and tools without feeling overwhelmed. Unfortunately, this was being executed with little recourse to trying to understand the lecturers' perceptions about the practicality, accessibility, capacity and usability of these technologies within their context. Therefore, some of the lecturers lack skills in using various online platforms for effective teaching and learning purposes. There is little published evidence on lecturers' experiences in using Moodle and other 
teaching and learning modes especially during the lockdown regulations prompted by the global outbreak of the COVID-19.

\section{Research Questions}

The main research question is: What are the online teaching and learning experiences of lecturers during a state of emergency in one of the UNAM satellite campuses?

\section{The research sub-questions are:}

.1 What are the UNAM lecturers' experiences with the use of Moodle and other online teaching platforms during the COVID-19 outbreak?

2 What opportunities do the UNAM lecturers perceive when using Moodle and other teaching modes during the COVID-19 outbreak?

3 What are the effective ways of online teaching practices that UNAM should implement?

\section{Literature review}

\section{Lecturers' experience in using online tools and other teaching modes in teaching}

Literature reveals that online education has grown over the last few years and new learning models in the market provide students with varied opportunities to fashion the learning modes that fit them best. Some scholars accentuate that online teaching and learning look promising and open up education to a larger section of the population than ever before (Wango, 2020; Saint, 1999; Asunka, 2008; \& Kiluk, 1994). Similarly, the study of Protski and Atkins (2016) on the experiences of lecturers in African, Asian and European universities in preparing and delivering online blended health research methods courses also reported participants feeling increased access to learning opportunities and made training more flexible and convenient to adults' students. On the contrary, the results indicated that they lacked capacity and support and found the task time-consuming. They needed to make compromises between course objectives and technological tools, in the context of poor infrastructure.

\section{Opportunities and strengths perceived when using online tools and other teachings modes}

Wani (2013) from Malaysia conducted a study about the relevance of e-learning in higher education and found that e-learning accommodates individual preferences and needs. At the same time, it empowers students of various backgrounds to have equal access to the best resources and referral material, lecture sessions, tutoring, and experienced lecturers. The study 
further indicated that e-learning improves the chances of students' collaboration with their lecturers and other peers through teaching and communication techniques which include case studies or scenarios, storytelling, demonstrations, role-playing, simulations, streamed videos, online references, personalized coaching and mentoring, discussion groups, project teams, chat rooms, e-mail, bulletin boards, tips, and tutorials.

\section{The challenges and obstacles perceive when using online modes}

The study of Protski and Atkins (2016) and that of Asunka (2008) specified that online teaching in higher education poses a great challenge as this mode of instruction delivery relies solely on the available information and communication technology infrastructure. Higher education institutions are currently in a state of crisis- having to cope with inadequate infrastructure and dwindling financial resources, whilst under increasing pressure to cater to larger student populations through online teaching and learning modes.

Assareh and Bidokht (2010) from Iran have conducted a study to outline a classification of barriers to e-teaching and e-learning. The study discovered three kinds of barriers such as students' financial problems, motivation, assessment of their progress, isolation from peers, inadequate skills and experience in distance learning, affection and social domain; lecturers lack of adequate knowledge about the e-teaching environment, and the difficulty for assessment of different domain progress; and curriculum ambiguity, quality, resource, teaching process, and evaluation. Salpeter (1998); Comas-Quinn, (2011); Protski and Atkins (2016) studies findings have shown that barriers include lack of teacher time, limited access and high cost of equipment, lack of vision or rationale for technology use, lack of teacher training and support, and current assessment practices that may not reflect what is learned with technology. The time needed by a lecturer to learn how to use the new technology includes the time the lecturer needs to become competent with the computer as a personal tool but also as an instructional tool. Similarly, Dube (2020) and Mohammad (2020) studies revealed that the e-learning teaching mode excludes many rural learners from teaching and learning, due to a lack of resources to connect to the internet, the learning management system, and low-tech software.

\section{Effective ways of online teaching practice}

Sun and Chen (2016) examined the positive aspects and strategies of the online learning and teaching process and how it has been implemented successfully in the United States of America (USA). The findings emphasised that effective online instruction depends on well-designed course content, the creation of a sense of online learning community and rapid advancement of technology. Tallent-Runnels et al. (2006) suggested that to support online education, universities train faculty and students, provide adequate technical 
support, give the faculty the release time for the online course development. Some of the online activities include creating online presentations, lecture notes, audio/video mini-lectures, individual or group activity assignments with scheduled deadlines, and providing guidance on how to use the technology on the course website (Garrison et al., 2009; Garrison \& Arbaugh, 2007; Kupczynski et al., 2010). Crawford-Ferre and Weist (2012) confirmed that lecturers who taught online courses reported that it took much time teaching online classes than face-to-face mode, while Keengwe and Kidd (2010) indicated that online teaching is easier than traditional classroom teaching.

\section{Methodology}

The study followed a mixed-methods approach which allowed for an understanding of the lecturers' experiences about e-teaching and learning amidst the COVID-19 pandemic. The study used a convergent parallel research design. The design was chosen as it allows researchers to collect quantitative and qualitative data concurrently and mix the two databases by merging the results during interpretation and data analysis (Creswell, 2012). The study was conducted at one of the UNAM satellite campuses. The population comprised of all the 98 lecturers who had used Moodle and other online teaching and learning platforms during the COVID-19 outbreak in Semester 1 (2020). A sample of 76 lecturers was purposively selected from January 2020 lecturing timetable. However, only 43 questionnaires were returned fully completed. The study used the following criteria to sample out the participants:

(a) a lecturer who has been lecturing at UNAM for more than two years; module(s).

(b) a lecturer should have either semester 1 or a year course

The qualitative data were collected through telephonic interviews and open-ended questions in the questionnaire whereas the quantitative data were collected via a survey questionnaire with a link that was emailed to respondents. During the telephonic interviews, the researchers were taking notes of the interviewees' responses which were thematically analysed and triangulated with the open-ended and survey responses. Some researchers cite interviewing by telephone as an easy way to gather contextual information for qualitative studies because telephone interviews tend to take less time than face-to-face interviews (Creswell, 2012). Data collected from open-ended questions and telephone interviews were analysed and categorised into themes and supported with illustrative quotes obtained from the participants while quantitative data were tabulated and analysed mainly by descriptive statistics with the use of Microsoft Excel. Participants were also asked about their training in computer skills as well as lecturing experiences. Table 1 gives a summary of the characteristics of the participants. 
Table 1. Socio-Demographic Characteristics of the Respondents

\begin{tabular}{clcc} 
No & Demographic Characteristics & Lecturers & \\
\hline 1 & Gender & Total & $\%$ \\
& Male & 17 & 40 \\
& Female & 26 & 60 \\
\hline 2 & Age range & & \\
& $20-25$ & 0 & 0 \\
& $26-30$ & 4 & 14 \\
& $31-35$ & 6 & 7 \\
& $36-40$ & 3 & 21 \\
& $41-46$ & 9 & 49 \\
\hline $37+$ & Lecturing experiences & 21 & \\
& $1-5$ & & 5 \\
& $6-10$ & 2 & 37 \\
& $11-15$ & 16 & 51 \\
& 16 and above & 3 & 12 \\
\hline & Highest qualifications & 22 & 72 \\
& B.Ed. & & 16 \\
\hline
\end{tabular}

Table 1 shows that more females' lecturers took part in the study compared to their male counterparts. The table further shows that $51 \%$ of lecturers have more than 16 years of lecturing experience, while $72 \%$ of lecturers are Master's degree holders.

For this study, the researchers sought ethical clearance from the University Research Ethical Committee (UREC), under the care of the participating Campus Research and Publications Committee. The participants were informed about the purpose of the study, the benefits of their participation and the benefits the study would contribute to the university. The researchers emphasised the voluntary nature of participating in the study, confidentiality and that their participation would not affect their work as researchers used unique numeric identifiers for the quotations, and removed any identifying information such as names from the questionnaire to ensure anonymity and confidentiality.

This study allowed the triangulation of findings from quantitative and qualitative databases to be corroborated to complement each other. Thereafter, researchers transcribed and familiarised themselves with the data from both approaches by coding, categorising, finding similarities and differences. Once the emerged themes were generated, the researchers wrote the final report on the issues about the use of online teaching and learning during the COVID-19 pandemic. Data reporting took the form of descriptive words, verbatim quotations, charts and tables. 


\section{Presentation of data and discussions}

The objective of this study was to explore the e-teaching and learning experiences of lecturers amidst COVID-19 at one of the UNAM satellite campuses. Presented below are the findings of the study. Quantitative data are presented first and the qualitative data are discussed following the order of research questions, the themes and sub-themes that emerged from the analysis.

\section{Lectures preparedness on Information Communication Technology usage}

This section mainly asked respondents' preparedness on using Information Communication Technology, for instance, computer skills, elearning modes they used in teaching and whether they had taught a module using Moodle before the COVID-19 outbreak.

Table 2 4.1. Lectures preparedness on ICT usage

NO

\subsection{Leetures preparedness on ICT usage}

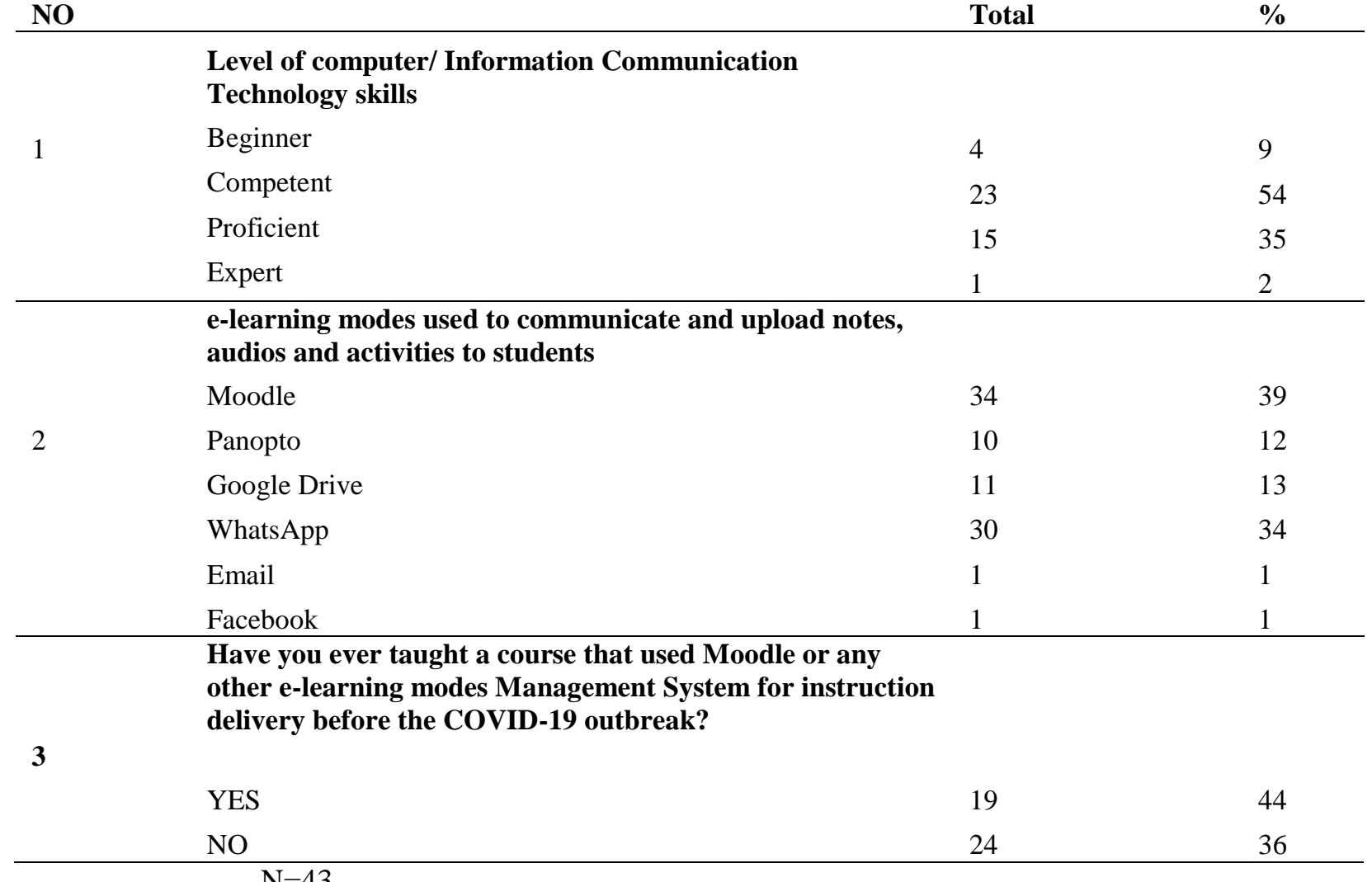

\section{$\mathrm{N}=43$}

Table 2 shows that $54 \%$ of the lecturers are competent, while $35 \%$ are proficient in using Information Communications Technology. 39\% of the lecturers used Moodle whereas 34\% used WhatsApp to communicate and upload notes, audios and activities to students. The least e-learning modes used were Email and Facebook with $1 \%$ each. It is surprising to note that although 
$36 \%$ of lecturers had never used Moodle as means of instructions delivery before the COVID-19 outbreak, they have managed to use e-learning modes to communicate with students during a time of crisis.

\section{Types of technology lectures have outside the university campus}

In this section, there were 4 statements that inquiry lecturers about the types of technology that they had access to outside the university campus. The results are summarised in Table 3.

\section{Table 3. Technology that lecturers have access to outside the university campus}

\begin{tabular}{|c|l|l|l|}
\hline$\#$ & Statements & Total & $\%$ \\
\hline 1 & I have a personal computer but no internet connectivity & 6 & 14 \\
\hline 2 & I have access to a computer only part of the time & 33 & 77 \\
\hline 3 & I only have access to a computer with the internet part of the time & 4 & 9 \\
\hline 4 & I have no access to a computer & 0 & 0 \\
\hline
\end{tabular}

\section{$\mathbf{N}=43$}

A perusal of Table 3 reveals that $77 \%$ of lecturers had access to a computer part of the time, while $14 \%$ of lecturers have no internet connectivity outside the university campus. It is worth noting that all the lecturers (0\%) had access to a computer. This has a significant impact on e-teaching as it made it easier to effectively communicate with students during the lockdown.

Factors that are likely to impact the ability to teach online courses

This section contained 10 statements that inquiry lecturers the factors that are likely to impact their ability to teach online courses. The results are summarised in Table 4 as follows:

\begin{tabular}{|c|c|l|l|l|l|l|}
\hline \multicolumn{2}{|c|}{ Table 4. Factors that are likely to impact the ability to teach online courses } \\
\hline & & $\begin{array}{l}\text { Highly } \\
\text { unlikely }\end{array}$ & Unlikely & Neutral & Likely & $\begin{array}{l}\text { Very } \\
\text { likely }\end{array}$ \\
\hline$\#$ & Statements & Number/\% & Number/\% & Number/\% & Number/\% & Number/\% \\
\hline 1 & $\begin{array}{l}\text { My inability to record audios via } \\
\text { Moodle/Panopto laptop? }\end{array}$ & $10 / 23 \%$ & $11 / 26 \%$ & $7 / 16 \%$ & $9 / 21 \%$ & $6 / 14 \%$ \\
\hline 2 & $\begin{array}{l}\text { The absence of technical assistance } \\
\text { to record and upload notes on } \\
\text { Moodle etc. }\end{array}$ & $10 / 23 \%$ & $12 / 28 \%$ & $10 / 23 \%$ & $7 / 16 \%$ & $4 / 9 \%$ \\
\hline 3 & $\begin{array}{l}\text { The absence of on-site training on } \\
\text { e-learning modes }\end{array}$ & $8 / 19 \%$ & $10 / 23 \%$ & $14 / 33 \%$ & $8 / 19 \%$ & $3 / 7 \%$ \\
\hline 4 & $\begin{array}{l}\text { Lack of regular electric power } \\
\text { supply on campus }\end{array}$ & $9 / 21 \%$ & $10 / 23 \%$ & $9 / 21 \%$ & $10 / 23 \%$ & $5 / 12 \%$ \\
\hline 5 & $\begin{array}{l}\text { My level of access to computer and } \\
\text { internet connectivity }\end{array}$ & $7 / 16 \%$ & $8 / 19 \%$ & $8 / 19 \%$ & $9 / 21 \%$ & $11 / 26 \%$ \\
\hline
\end{tabular}




\begin{tabular}{|l|l|l|l|l|l|l|}
\hline 6 & $\begin{array}{l}\text { My level of access to library books } \\
\text { and other resources }\end{array}$ & $9 / 21 \%$ & $9 / 21 \%$ & $14 / 33 \%$ & $9 / 21 \%$ & $2 / 5 \%$ \\
\hline 7 & $\begin{array}{l}\text { The University campus } \\
\text { environment }\end{array}$ & $5 / 12 \%$ & $11 / 26 \%$ & $14 / 33 \%$ & $9 / 21 \%$ & $4 / 9 \%$ \\
\hline 8 & $\begin{array}{l}\text { My level of computer and internet } \\
\text { skills }\end{array}$ & $10 / 23 \%$ & $6 / 14 \%$ & $8 / 19 \%$ & $15 / 35 \%$ & $4 / 9 \%$ \\
\hline 9 & My other personal obligations & $8 / 19 \%$ & $9 / 21 \%$ & $13 / 30 \%$ & $10 / 23 \%$ & $3 / 7 \%$ \\
\hline
\end{tabular}

\section{$\mathbf{N}=43$}

It appears that the majority of lecturer's abilities to teach online courses were very likely (9\% and likely (35\%) impacted by their level of computer and internet skills, very likely (7\%) and likely (19\%) by the absence of on-site training on e-learning modes; very likely (9\%) and likely $(35 \%)$ by the level of access to computer and internet connectivity. It is worth noting from the table that the least factor that impacted the online teaching courses was the university campus environment.

\section{Lecturers' opinions about the use of Moodle}

In this section, lecturers were asked to respond to 7 statements about the use of Moodle as an e-learning platform. The results are summarized in Table 5 as follows:

\section{Table 5. Lecturers' opinions about the use of Moodle}

\begin{tabular}{|c|c|c|c|c|c|c|}
\hline & & Very easy & Easy & Neutral & Difficult & $\begin{array}{c}\text { Very } \\
\text { Difficult }\end{array}$ \\
\hline \# & Statements & Number/\% & Number/\% & Number/\% & Number/\% & Number/\% \\
\hline 1 & $\begin{array}{l}\text { Connecting and logging } \\
\text { into Moodle anytime on campus }\end{array}$ & $9 / 21 \%$ & $14 / 33 \%$ & $7 / 16 \%$ & $9 / 21 \%$ & $4 / 9 \%$ \\
\hline 2 & $\begin{array}{l}\text { Connecting and logging } \\
\text { into Moodle from anywhere }\end{array}$ & $10 / 23 \%$ & $9 / 21 \%$ & $11 / 26 \%$ & $11 / 26 \%$ & $2 / 5 \%$ \\
\hline 3 & $\begin{array}{l}\text { Getting technical support when } \\
\text { having difficulties with Moodle or } \\
\text { other computer problems }\end{array}$ & $3 / 7 \%$ & $10 / 23 \%$ & $7 / 16 \%$ & $8 / 19 \%$ & $6 / 14 \%$ \\
\hline 4 & $\begin{array}{l}\text { Uploading of notes, assessment } \\
\text { activities and assignments on Moodle } \\
\text { and other e-learning modes }\end{array}$ & $5 / 12 \%$ & $13 / 30 \%$ & $12 / 28 \%$ & $11 / 26 \%$ & $2 / 5 \%$ \\
\hline 5 & $\begin{array}{l}\text { Communicating with other lecturers } \\
\text { through Moodle and other e-learning } \\
\text { modes }\end{array}$ & $5 / 12 \%$ & $14 / 33 \%$ & $9 / 21 \%$ & $13 / 30 \%$ & $2 / 5 \%$ \\
\hline 6 & $\begin{array}{l}\text { Communicating with students } \\
\text { through Moodle and other e-learning } \\
\text { modes }\end{array}$ & $7 / 16 \%$ & $10 / 26 \%$ & $7 / 16 \%$ & $15 / 35 \%$ & $4 / 9 \%$ \\
\hline 7 & $\begin{array}{l}\text { Contributing to course discussions } \\
\text { through the discussion forum } \\
\text { of Moodle }\end{array}$ & $5 / 12 \%$ & $9 / 21 \%$ & $14 / 33 \%$ & $13 / 30 \%$ & $2 / 5 \%$ \\
\hline
\end{tabular}


$\mathrm{N}=43$

An analysis of Table 5 illustrates that the majority of the lectures (21\%) found connecting and logging into Moodle anytime on campus very easy, while $(33 \%)$ found it easy. In addition, $(23 \%)$ of lecturers found connecting and logging into Moodle from anywhere very easy whereas $(21 \%)$ found it easy. Consequently, few lecturers (14\%) indicated that getting technical support when having difficulties with Moodle or other computer problems is very difficult. This finding shows that lecturers did successfully used Moodle despite a lack of in-site training and computer skills.

\section{Theme 1: Experiences in using Moodle and other teaching modes during the COVID-19 outbreak}

(a) Wellness of using Moodle

The world has moved from classroom face-to-face teaching and lecturing towards technology system user friendly. Participants expressed that they do enjoy using Moodle, a platform whereby one teaches using a lively virtual classroom, interacting with students wherever they are, upload a test and or a quiz, posting announcements and notifications, chat with the students while the lesson is in progress. In addition, participants stressed that Moodle is efficient as it allows interaction between the lecturers and students since no gathering is required during the COVID-19 pandemic. Lecturers articulated their experiences in using Moodle during COVID-19 by saying that: "Overall Moodle is a good one...yuh, it wasn't good at the beginning, nevertheless, I acquired new knowledge, since it was a learning process". In addition, one participant indicates that: "I have been using online teaching before the outbreak of COVID-19 and it made my teaching effective".

On a different note, another participant applauds that: "It wasn't good at the beginning... it was hectic, confusing, but now I do have the skills to use e-learning platforms".

Participants further alluded that:

I found using Moodle interesting, however, with few challenges... the network in most cases was very poor, especially in remote areas that resulted in little participation from students, few attendances, lack of reliability with assessment activities, and complaints from students daily that Moodle is down.

The use of Moodle created a mutual understanding and interactions between the lecturers and students as $65 \%$ of lecturers agreed that the University of Namibia is capable of offering fully online teaching. Further the use of Moodle facilitated effective interpersonal relationships among the fellow lecturers and students as they shared ideas, knowledge and skills by 
supporting one another in using various online platforms. This is supported by Wani (2013) that e-learning improves the chances of students' collaboration with their lecturers and peers through e-teaching and communication techniques.

\section{Theme 2: Opportunities and strengths UNAM lecturers perceived} when using Moodle and other teaching modes during the COVID-19 outbreak

\section{(a) Learning opportunity}

The analysis of data discovered opportunities and strengths of using elearning platforms by lecturers. Thus, $47 \% \%$ of lectures agreed that they were satisfied with the way they conducted online teaching. Similarly, participants expressed that using Moodle as a mode of instruction delivery created an opportunity for lecturers to learn more about technological skills which they did not know before the Coronavirus outbreak. They indicated that continuing teaching despite the lockdown strengthened their ability to thrive within an uncomfortable environment. One participant had this to explain: "The opportunity is that one may become an expert in using Moodle and other related e-learning tools. You know what... Learning Management Systems such as Moodle is designed to support online mhm... and I have learned to organise learning resources for my students. Further, one participant remarked that "I am becoming the expert in using online platforms such that... I managed to set my tasks assessment on Moodle."

The results of the study acknowledged that lecturers had an opportunity to learn new skills despite not having prior experience in online teaching and learning as well as online course design and pedagogy. The use of Moodle saved time and reduced the chances of spreading the virus since no gatherings were required. These findings are in line with the study of Protski and Atkins (2016) which reported participants feeling increased access to learning opportunities and that online learning made training more flexible and convenient to students.

\section{(b) Online Teaching large classes at once}

The core modules which are taken by all students at a specific study level may have 500 students or more. For instance, online teaching through the Big Blue Button tool created an opportunity for lecturers to teach large class groups at once. One participant narrated that:

My core module usually has close to 500 students. Normally, they get split into two groups as per their phases; for instance, the Pre-lower primary and secondary phases are grouped whereas the upper primary phase stands alone as this one mostly has a large number of students and this kind of arrangement doubled my workload. 
On a similar note, the participant added that automated marking of assessment activities and exporting students' grades made my work easier compared to the traditional way I used before.

The marking of assignments via Moodle reduced the work of the lecturers as the icon options allowed lectures to save comments that can be retrieved later and used to other students who happened to have similar challenges. This result is in agreement with Hoq (2020) study findings that many learners can be engaged at the same time, thus decreasing the time required for the program. Further, the material once prepared is everlasting, and maybe re-examined many times, the saved time in making materials may be utilized by the lecturers to improve their advanced level of intellectual elearning. Further, online teaching made grading of assessment activities on Moodle easier. These findings are in line with other reports where teachers verbalized that the automated marking of the tests reduced the time and effort needed to grade assessments (Hoq, 2020; Wango, 2020).

\section{Theme 3: Challenges or obstacles perceived in using Moodle}

\section{(a) Network and connectivity}

The majority of respondents pointed out various challenges and obstacles they experienced in using Moodle and other e-learning related tools. It has alluded that the network was overloaded and accessing the internet became a problem as it was slow to upload notes and the content to students. Lecturers stated that not all students had access to the internet neither all had smartphones and laptops. As a result, students complained constantly. It was further reported that little participation from students hampered teaching and learning progress as lecturers had to repeat the same lessons from time to time. Some of the extracts...

Mhm...using Moodle was a bit hard for me... but one has to learn the hard way". "It was a bad experience since I was not able to access Moodle...eish! Moodle was not opening and if it opens, it keeps on loading until you give up. Sometimes it doesn't open at all" I struggled... I have skills of using the computer, but a beginner in using Moodle...am taking a slow pace in learning, therefore I didn't enjoy the use of online much, the reality is that the system was not accessible to most of us.

With regards to network and connectivity, participants expressed the following: "Not all students had internet access... so... one can experience a situation whereby you have a class of twelve [12] students over a total number of seventy-five [75] and above". Another participant claimed that some of the students were not able to connect to the virtual classroom due to the system which was on and off most of the time, consequently, they missed out on the life lessons. On reflection concerning the challenges in using Moodle, it was 
acknowledged that some of the lecturers didn't have the opportunity to reach all the students which created a knowledge gap on the part of the students. During the telephonic interview, one participant recounted that "I had a bad experience... aaa... I was not able to access Moodle as it was not opening and when it opens... it keeps loading until I gave up".

Although the study underscored the advantages of using Moodle, at the same time it highlighted concerns on low attendance of virtual classes that prevented students' benefiting from online teaching. Moodle can be effective if all students can have access to the Internet. However, this finding contradicts the situation in Ghana where Asunka (2008) reported that access and ability to use the technology was not an issue as students could log into the course platform when they wished. Most of the students were occasionally able to engage in forum discussions both with peers and with the instructor. Concurrently, limited students' participation by way of attending online conferencing and online forum discussions appears to be a widespread phenomenon (Asunka, 2008), and this has been attributed to factors such as lack of computer skills on both lecturers and students alike, technical difficulties, and inadequate equipment at the campus. In support of the above, Hoq (2020), stated that the accomplishment of e-learning relies on the adequate Internet connection and satisfactory bandwidth is required at several stages to safeguard appropriate downloading.

\section{(b) Control over assessment/Quality assessment compromise}

Opinions on the quality and credibility of online assessments seem to vary according to the value credits or the modules year level. It was also noticed that online assessment was satisfactory for first-year modules. On a different note, participants had concerns over online assessment for the final year modules. Participants were speculative if it was the students themselves who were doing the activities or perhaps other family members or former students were doing the activities on their behalf. Therefore, in comparison with face-to-face teaching and assessment through online teaching,79\% of lecturers disagreed that online teaching is effective compared to face-to-face teaching.

In connection with the online assessment quality problem, one of the participants remarked: "I feel online activities...really promote cheating and compromise quality....in fact students take tests and examinations in groups...ooh...lecturers have no proper control over online assessments". In the same vein, reflection on the online assessment control was recalled by one lecturer that "I have no trust on online assessment...simply because... I am not assured and again convinced if it is the students who did the task or is the former students or anyone else".

Credibility of online assessment generated discussions among the lecturers as some were disproving the use of it. However, the discussion 
outcomes outpaced the negativity. Equally, Assareh and Bidokht (2010) study in Iran also documented the difficulty for online assessment of different domains progress and curriculum; ambiguity, quality, resource, teaching process, evaluation.

\section{(c) Lack of technical skills}

There were common reports of problems with the technology which could not be attributed to the fact that many participants were new to online teaching. The majority of participants experienced technical problems, which affected mainly the online conferencing system, the electronic assignment submission on the system, and the audio recording tool. In a low voice, participants had this to say: "Seriously...whenever I press the computer wrongly..., aam... in most cases, it is difficult to bring it back to the normal functioning without the involvement of the Technician, which is hard to get help from... Imagine ... you are in the middle of the lesson mhn... and the power goes off... this disrupts the whole teaching process and you can get frustrated".

Some of the lecturers who participated in the study had little experience of using online learning and had not been upskilled in online teaching and computer skills. This finding is not unique to the current study as Dube (2020) found similar findings where participants also reported a lack of ICT as a hindrance to online teaching. Another study by Comas-Quinn (2011) also identified a lack of skills and experience among much academic staff when it came to online teaching, which, in turn, impacted negatively on students learning and engagement. Hoq (2020) study found out that in many institutions there is not enough mechanical backing to operate e-learning programs properly and suggested that knowledge and expertise of information technology at the learners' stage is mandatory to embrace e-learning.

\section{Theme 4: Suggestions on the online teaching and learning strategies that UNAM should implement}

(a) Training of staff and students

Respondents expressed their opinions that online and e-learning tools were unexpectedly implemented because of the COVID-19 outbreak. As it is shown from their responses that lecturers need the training to be well equipped with skills and knowledge needed during this digital era. An example of an extract from the data is as follows: "I thought, the environment would be conducive, as I expect training first before online teaching execution".

"Training on how to access and use e-learning resources is necessary".

For online teaching and learning to run smoothly, both staff and students need sufficient training on computer skills and the use of various 
online platforms. Similarly, to improve accessibility and connectivity, Unam should provide easy access to campus-based technical support. This finding is in line with Keengwe and Kidd (2010) study that accentuate that online education is a new dynamic to both novice and veteran lecturers, thus, adequate professional development is necessary, which may include effective course design, instruction, implementation, and evaluation. Comas-Quinn (2011) also supported lecturers to be trained to become confident users and effective supporters of their students. She maintained that both lecturers and students need to know how to use new technologies and why they should use them.

\section{(b) Provide adequate equipment}

Respondents expressed their opinions on the equipment availability at Unam for lecturers to implement online and e-learning tools during the COVID-19 outbreak. The participants suggested that Unam needs to purchase adequate computers and improve on the internet server to cater to many users at the same time. Further, it was suggested that having sufficient computers may allow students to write online examinations and tests on campus in one controlled venue to minimize cheating and copying. The findings of this study further support existing evidence that reported inadequate access to library computers due to insufficient numbers available (Hako \& Shikongo, 2019). Furthermore, the participants supported the provision of tablets and internet devices for both students and academic staff. This finding is in line with other reports where teachers verbalized that the internet was unreliable or "off" most of the time, and this unreliability delayed the uploading of the notes and assessment activities for students on time.

\section{(c) Orientation program}

The inadequate orientation program information is given to the firstyear students and newly appointed lecturers at the University of Namibia compromises learning. Apart from the information on course selection (i.e. pre-requisite modules) and touring of the whole campus for students to know where to find lecture halls, it is also crucial that both students and new lecturers are oriented on how to access and use Moodle without difficulties. Participants of this study advocated for the provision of gadgets and other equipment to new lecturers and students, and specifically to students from poor backgrounds for them to continue learning without too many setbacks. This finding is consistent with Hako and Shikongo (2019) study that supports the idea of the current orientation program to be reviewed and strengthened to better cater to both lecturers and students' success by helping those who are lacking technological skills and financial resources. 


\section{Limitations of the study}

The data were collected through telephone interviews and a selfreported questionnaire that was sent to lecturers' emails and some might not be able to access the link due to poor connectivity. Further, using a questionnaire instead of a face-to-face interview might limit respondents to give sufficient information as required, but giving them extra space in the questionnaire might help them to elaborate more on their answers. Furthermore, the study was conducted at one site which may limit the generalizability of the findings although there are significant findings with implications to other study settings.

\section{Conclusion}

The use of online teaching has become inevitable during the COVID19 pandemic and enabled learning to continue during this difficult time. The online teaching became prominent although the individuals who are using it faced various challenges as not all of them are skilful equipped with the necessary practical skills. The fact that only 43 of 76 lecturers participated in the study, it might have affected the findings. However, this study demonstrated that lecturers perceive online teaching as a learning opportunity to enhance their use of technology in teaching despite the challenges that are associated with it. The study confirmed the viability of teaching a large number of students at once despite the poor network coverage in the country. Providing support for both lecturers and students as well as improving technological infrastructure can enhance the online teaching experience of educators in institutions of higher learning. The results of the study accentuate lecturers' experiences and challenges, thus encouraging the UNAM Management to mitigate such challenges while capitalizing on experiences. 


\section{References}

Assareh, A., \& Hosseini, B.M. (2011). Barriers to e-teaching and e-learning. Procedia Computer Science, 3,791-795.

Asunka, S. (2008). Online Learning in Higher Education in Sub-Saharan Africa: Ghanaian students' experiences and perceptions. International Review of Research in Open and Distance Learning RG Journal Impact: 1.35.

Bhardwaj, A., Nagandla, K., Swe, K.M.M \& Abas, A.B.L. (2015). Academic Staff Perspectives Towards Adoption of eLearning At Melaka Manipal Medical College: Has E-Learning Redefined Our Teaching Model. Kathmandu Univ Med J; 49(1):128. https://doi.org/10.3126/kumj.v13i1.13746 PMID: 26620743

Comas-Quinn, A. (2011). Learning to teach online or learning to become an online teacher: an exploration of teachers' experiences in a blended learning course. ReCALL, 3(03), pp. 218-232. DOI: 10.1017/S0958344011000152.

Crawford-Ferre, H. G., \& Wiest, L. R. (2012). Effective online instruction in higher education. The Quarterly Review of Distance Education, 13(1), 11-14.

Creswell, J.W. (2012). Research design. Mixed methods approach. (3rd edition). London: Sage Publications.

Dube, B. (2020). Rural Online Learning in the Context of COVID-19 in South Africa: Evoking an Inclusive Education Approach. Multidisciplinary Journal of Educational Research, 10(2), 135-157. DOI: 10.4471/remie.2020.5607

Garrison, D. R., Anderson, T., \& Archer, W. (2009). Critical thinking, cognitive presence, and computer conferencing in distance education. American Journal of Distance Education, 15(1), 7-23.

Hako, A. N., \& Shikongo, P.T. (2019). Factors hindering students from completion of studies within the prescribed duration: a case study of the public university in Namibia. JISTE, 23 (1), 39-52.

Harvey, B. (2003). Investing in technology: The impact on student learning. ERIC Digest. ERIC Clearinghouse on Information \& Technology. ERIC Document No: ED479843. http://www.ericdigests.org/2005-2/technology.html

Hoq, M.Z. (2020). "E-Learning during the Period of Pandemic (COVID-19) in the Kingdom of Saudi Arabia: An Empirical Study." American Journal of Educational Research, 8, (7), 457-464. Doi: 10.12691/education-8-7-2.

Kiluk, J.A. (1994). Meta-analytic studies of findings on computer-based instruction. In E.L. Baker \& H.F. O’Neal, Jr. (Eds.), Technology assessment in education and training. Hillsdale, NJ: Lawrence Erlbaum.

Kupczynski, L., Ice, P., Wiesenmayer, R., \& McCluskey, F. (2010). Student perceptions of the relationship between indicators of teaching presence and success in an online course. Journal of Interactive Online Learning, 9(1), 23-43.

Ministry of Health and Social Services [MoHSS]. (2020). COVID-19 update Centre. Windhoek: Namibia.

Ndala, D. K. (2020). Impact of Covid-19 on Higher Learning, Namibian. 21 April: 2020.

Protski, M. \& Atkins, S. (2016). The experiences of lecturers\& for the ARCADE consortium (2016 in African, Asian and European Universities in preparing and delivering blended health research methods courses: a qualitative study, Global Health Action, 9:1, DOI: 10.3402/gha. v9.28149 
Saint, W. (1999). Tertiary distance education and technology in Sub-Saharan Africa. Washington DC: The World Bank: DEA Working group on higher education.

Salpeter, J. (1998). Taking stock: What's the research saying? Technology and Learning, 18(9), 24-25.

Sun, A., \& Chen, X. (2016). Online education and its effective practice. A research review. Journal of Information Technology Education: Research, 15, 157-190. Retrieved from http://www.informingscience.org/Publications/3502

Tallent-Runnels, M. K., Thomas, J. A., Lan, W. Y., Cooper, S., Ahern, T. C., Shaw, S. M., \& Liu, X. (2006). Teaching courses online: A review of the research. Review of Educational Research, 76(1), 93- 135.

The Centre for eLearning and Interactive. UNAM eLearning Policy (2018). https://elearning.unam.edu.na/course/index.php?categoryid=13

Wani, H.A. (2013). The Relevance of E-Learning in Higher Education. Journal of online learning, 3(2), 221-228.

Wango, G. (2020). Tips for Dealing with High Anxiety in the Age of COVID-19: https://news.wttw.com/2020/03/23/tipsdealing-high-anxiety-age-covid-19. 